\title{
Um diálogo entre a filosofia, a educação e a política: limiares entre a moral, o legal e a reificação
}

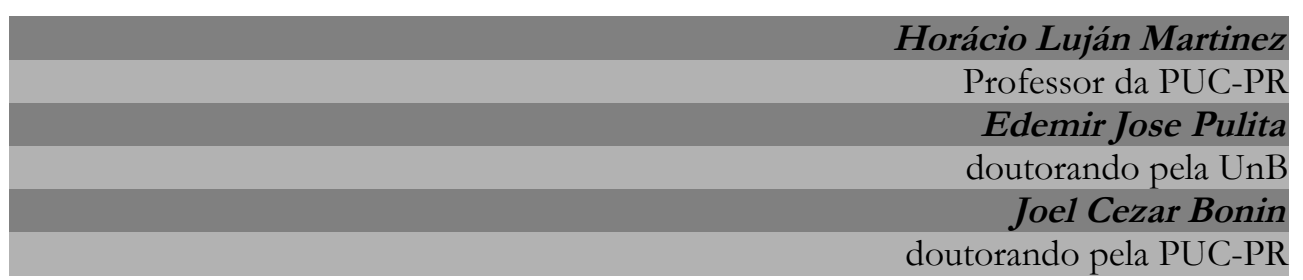

\section{Resumo}

O objetivo desta reflexão é estabelecer um diálogo entre os espaços da educação, da filosofia e da política, buscando construir pontes entre eles. Seu embasamento teórico se refere à crítica ao capitalismo e ao conceito de reificação, a partir de autores da Escola de Frankfurt, de Foucault, de Benjamin e outros autores. Esse texto também faz referência aos acontecimentos recentes que envolvem a presença (ou ausência) dos três elementos citados anteriormente. Viuse que a educação enquanto estratégia política de governo, foi solapada por medidas governamentais nas esferas estaduais e federal, ao imporem ações que não promoveram o seu devido desenvolvimento. Diante disso, tentamos abordar no texto que segue a falsa ideia de que a "educação é para todos" e que é preciso um olhar político-filosófico para compreender tal assertiva, pois vê-se que os modos de abordagem que discutem a educação em nosso país são enfaticamente mais alienantes e reificadores do que emancipatórios e democráticos.

Palavras-chave: filosofia; educação; política.

\begin{abstract}
The purpose of this reflection is to establish a dialogue between the areas of education, philosophy and politics, seeking to build bridges between them. Its theoretical foundation refers to the critique of capitalism and the concept of reification, from authors of the Frankfurt School, Foucault, Benjamin and other authors. This text also refers to recent events involving the presence (or absence) of the three elements mentioned above. We have seen that education as a political strategy of the government was undermined by government measures in state and federal, to impose actions that did not promote their proper development. Therefore, we tried to address in the text that follows the false idea that "education is for everyone" and that it takes a political and philosophical look to understand this assertion, because it is seen that the approach modes discussing education in our country are emphatically more alienating and reifying than emancipatory and democratic.
\end{abstract}

Keywords: philosophy; education; policy.

Filosofia e Educação [rfe] - volume 8, número 1 - Campinas, SP

Fevereiro-Maio de 2016 - ISSN 1984-9605 - p. 133-162 


\section{Os desafios da Pátria Educadora}

temática da educação não passa incólume nem mesmo nos
setores e nas dimensões da vida pública que pouco dependem ou
se ligam a ela. Para citar dois exemplos, a produção petrolífera e o conceito de família. A reflexão acerca da educação atinge espaços de interação que vão desde a mesa do jantar até os bastidores do Congresso Nacional. Por isso, não é de se estranhar que as faculdades consideradas licenciaturas entrem neste embate diante da temática da educação, como por exemplo, a filosofia, a história, a geografia, a matemática, a pedagogia, entre outras. Porém, a discussão começa a causar alvoroço quanto se tenta pensar este campo polêmico, polissêmico e polifônico a partir da possibilidade do estabelecimento de um fundamento científico ou de princípios filosóficos que lhe deem sustentação em termos de conceitos, práticas, reflexões e políticas.

Buscamos, nos limites deste artigo, discutir as interfaces entre os campos da educação e da filosofia, sob o foco da política, tanto em termos teóricos quanto em termos práticos. Segundo Oliveira (2012, p. 10ss) tanto o empenho filosófico quanto a prática educativa, se vistos numa perspectiva dialógica e convergente entre a Filosofia e a Educação por filósofoseducadores ou educadores-filósofos, tem muito a enriquecer a reflexão, o diálogo, a análise e a construção de conhecimentos em ambas as áreas, seja no saber filosófico ou na ciência pedagógica. Relembrando o período clássico da filosofia grega, Botter (2012) é pontual ao afirmar que "a filosofia é pedagógica e a pedagogia é filosófica, assim como a filosofiapedagogia é política e a política é filosófico-pedagógica” (p. 19-20).

Diversos acontecimentos recentes demarcam, por outro lado, uma grande dissociação entre o mundo filosófico, pedagógico e político. 
Vivemos dias nebulosos nos quais não se nota mais a aproximação entre filosofia, política e educação. "Um povo que não conhece a sua história está condenado a repeti-la”. Esse jargão tão propalado é uma máxima da profunda separação do cidadão comum como o mundo que o cerca.

Desse modo, queremos aprofundar a correlação que existe entre o mundo da TV ou das tecnologias comunicacionais digitais e do mundo vivido, entre a realidade que se escancara diante de nossos olhos e a realidade produzida pelo mundo midiático, e um pouco sobre a realidade em que se constrói a educação no Brasil, tão midiaticamente utilizada pela política e seus sujeitos. Uma pátria que se pretende educadora deve priorizar e construir diálogos entre as práticas educativas, as ações políticas e os saberes filosóficos.

\section{Que país e mundo são esses?}

"Vivemos esperando dias melhores" (Jota Quest, 2000). Essa frase presente na canção Dias melhores da banda Jota Quest, lançada no ano que fecha o segundo milênio da era cristã, reflete claramente a expectativa que muitas pessoas têm diante do mundo e da vida. Tal esperança já se manifestava no início do século XX, um século que marcou historicamente a existência humana, pois se acreditava que todas as inovações e invenções decorrentes da Revolução Industrial se plenificassem na aurora desse tempo. Porém, o que vemos hoje, em pleno século XXI, é que a vida, em diversos aspectos e sob vários pontos de vista, está sendo suprimida e mensurada, controlada e vigiada, manipulada e reificada.

É evidente que não se está afirmando nada de novo, não há aqui uma pretensão de expor nada de inovador, até porque tal palavra se apresenta, por inúmeras vezes, como puramente ideológica. O que se esconde por trás

Filosofia e Educação [rfe] - volume 8, número 1 - Campinas, SP

Fevereiro-Maio de 2016 - ISSN 1984-9605 - p. 133-162 
de toda inovação pode ter um "quê" de mascaramento. O que exige cada vez mais um exercício hermenêutico profundo, pois quer se saber se a inovação apresentada pelas principais vias de comunicação deseja ou não esconder a verdade, seja a coloquial, a impressa ou a midiática. Essa realidade é ainda mais impactante quando se vê as crescentes denominações da sociedade atual enquanto era da informação e/ou do conhecimento.

Um dos maiores problemas da comunicação atual repousa na angústia de dizer algo mesmo que não seja necessário dizer nada. Notícias sensacionalistas, propagandas espetaculares, telejornais impregnados de falsas verdades. Como já havia escrito Walter Benjamin (1985, p. 202), citando Villemessant, jornalista que fundou o Figaro: "para meus leitores, o incêndio num sótão do Quartier Latin é mais importante que uma revolução em Madri”. Juntamente com a televisão, o mundo da tecnologia preencheu um vazio que ainda permanece oco. Na substituição da comunicação oral e no afã de induzir todos a desejarem as mesmas coisas, o ser humano ainda permanece desamparado. Na substituição do sagrado transcendental, o ser humano busca o sagrado que emana dos próprios objetos, sem se dar conta que os objetos estão para ele e não o contrário. A fé dogmática de outrora em um mundo no qual predominava a ideologia cristã, se transubstancializou em uma fé dogmática extremista e fundamentalista não apenas presente nos estabelecimentos e nos postos da fé, mas agora mais presente ainda através dos meios de comunicação digitais em rede.

Sartre (1987, p. 6) ao afirmar que a "existência precede a essência" foi e continua sendo mal-interpretado, pois é cada vez mais evidente a noção de que as pessoas anseiam por uma existência sem essência. $O$ fato de que primeiro existimos e depois encontramos a nossa essência ainda permanece uma incógnita, pois é cada vez mais explícito que as pessoas querem apenas existir. Tal reflexão se maximiza sobremaneira em uma sociedade que está

Filosofia e Educação [rfe] - volume 8, número 1 - Campinas, SP

Fevereiro-Maio de 2016 - ISSN 1984-9605 - p. 133-162 
imersa e envolta em uma profusão midiática e tecnológica sem precedentes na História. Nesta sociedade de consumo, altamente tecnologizada e midiatizada, o ter, o ser e o estar se confundem com o comprar, o possuir e o utilizar. A mistura contemporânea de hedonismo e de maniqueísmo encontrou nas tecnologias digitais uma levedura extremamente potente de fermentação.

Para se fazer uma escolha sincera por uma reflexão mais aprofundada, é mister compreender que justamente no início do século passado, os estudiosos da Escola de Frankfurt e alguns outros a eles relacionados, analisaram as possíveis consequências do avanço tecnológico, primeiramente, refletindo sobre o desenvolvimento bélico usado na $1^{\mathrm{a}}$ e na $2^{\mathrm{a}}$ Guerras Mundiais e suas consequências para a vida posterior. Adorno (2010, p. 11), neste sentido, afirma que "o desenvolvimento da sociedade a partir da Ilustração, em que cabe importante papel à educação e formação cultural, conduziu inexoravelmente à barbárie”. Fazendo uma crítica, tendo por base a premissa de "que Auschwitz não se repita!" (2010, p. 21), o filósofo reflete a respeito da ideologia do progresso:

Em outras palavras: a questão do poder e da ética, a dominação autoritária ou a democracia, não são examinadas como fundantes ou existências primárias [...] mas derivadas no curso do desenvolvimento determinado da formação social. Auschwitz faz parte de um processo social objetivo de uma regressão associada ao progresso, um processo de coisificação que impede a experiência formativa, substituindo-a por uma reflexão afirmativa autoconservadora, da situação vigente. Auschwitz não representa apenas o genocídio num campo de extermínio, mas simboliza a tragédia da formação na sociedade capitalista (Adorno, 2010, p. 22). 
Pensar acerca dos avanços tecnológicos e das mudanças que tais transformações aportam, não implica em uma pura negação dos benefícios que estes trouxeram para a vida humana, mas, ao contrário serve para afirmar que uma visão de mundo baseada somente nas tecnologias se torna escrava e refém de um sistema de controle e vigilância da vida humana, tão proficuamente expresso por Michel Foucault (1987) em Vigiar e Punir. As tecnologias em geral e, principalmente, as de controle e de vigilância nascem de modo mais claro no século XIX, mas se transformam em sistemas no século seguinte. A lógica desse controle e desse poder transmuta-se do espaço das penitenciárias, dos hospitais e das fábricas para o mundo vivido, isto é, não há como escapar do "olho que tudo vê", que passa de uma mera expressão metafísica, segundo os moldes cristãos, para algo mais concreto e prático.

Desse modo, as formas de controle se expandem e, tal qual um deus invisível e poderoso, opera sobre os seres humanos de modo cada vez mais eficaz. Na medida em que novos meios de comunicação, tais como smartphones e notebooks, se tornam cada vez mais democráticos e as pessoas tem um acesso maior à rede mundial de computadores via conexão digital, o mundo da informação, da comunicação e da expressão é cada vez mais propalado e reproduzido. Porém, surge-nos uma questão essencial: isso efetivamente tornou a vida das pessoas algo melhor?

Por esse viés e sublinhando o impacto que qualquer meio produz na sociedade, McLuhan (2007, p. 25) escreve que os "meios levam em conta não apenas o 'conteúdo', mas o próprio meio e a matriz cultural em que um meio ou veículo específico atua". Diante disso, então, "cada produto que molda uma sociedade acaba por transpirar em todos e por todos os seus sentidos" (McLuhan, 2007, p. 37), ou seja, por mais ou menos influenciados que sejamos, conscientes ou não, estamos imersos no ambiente digital e 
virtual por toda parte e em todas as dimensões de nossas vidas. A conclusão de McLuhan (2007, p. 403) do livro Os meios de comunicação como extensões do homem é envolta em um realismo pessimista nebuloso: "o temor pânico ante a automação em escala mundial, é uma projeção no futuro do especialismo e da padronização mecânica - que agora pertencem ao passado". Nesse sentido, podemos citar um trecho da obra de Deleuze (Conversações) que corrobora McLuhan.

É fácil fazer corresponder a cada sociedade certos tipos de máquina, não porque as máquinas sejam determinantes, mas porque elas exprimem as formas sociais capazes de lhes darem nascimento e utilizá-las. As antigas sociedades de soberania manejavam máquinas simples, alavancas, roldanas, relógios; mas as sociedades disciplinares recentes tinham por equipamento máquinas energéticas, com o perigo passivo da entropia e o perigo ativo da sabotagem; as sociedades de controle operam por máquinas de uma terceira espécie, máquinas de informática e computadores, cujo perigo passivo é a interferência, e, o ativo, a pirataria e a introdução de vírus (Deleuze, 2013, p. 227).

“Ter o mundo na palma de sua mão" é um slogan de uma operadora de telefonia móvel que cada vez mais possui novos adeptos ou seguidores. Nesse caso, é fundamental nos atentarmos para o uso da palavra "seguidor". A frase messiânica de Jesus: "Venha e siga-me" (Bíblia, 1991, p. 1265) é um símbolo que traduz uma das mais fortes verdades que vemos em nosso tempo, contudo, o seguimento é cego ou, no mínimo, caolho. A postura de abandono das próprias escolhas, da ausência de autonomia, a falta de um exercício refletido acerca daquilo que se quer, resumem o "cardápio do dia". O que se quer para além das migalhas e da sensação de euforia meteórica e instantânea? Ainda não se sabe, pois nos dias de hoje ainda não há uma 
certeza de qual será a reação dos inúmeros Narcisos digitais diante de seus lagos-telas. Contudo, a profusão midiática, tecnológica e informacional está em franco desenvolvimento e pesquisas das áreas de mídias, comunicação e educação estão debatendo suas características, movimentos, sujeitos, tempos e espaços sob diversos enfoques, discursos e ideologias. Diante disso, cabe a indagação de qual será o resultado: se emancipatório ou se catastrófico.

Desse modo, vê-se que a vida humana foi reduzida ao constante despertar do desejo. O desejo de se querer algo, que ao fim e ao cabo, não se quer. As manifestações efusivas do desejo estão presentes na vida infantil e adulta. As crianças encontram constantemente estímulos para almejarem algo que não está nelas, mas que precisam ser introjetados para se sentirem partícipes de grupos sociais. As habilidades motoras, o ato de brincar, o ato de estabelecer vínculos afetivos sinceros são substituídos por produtos que criam agora um laço de inclusão social, mas que não são mais dirigidos pelo “estar-com" ou "com-um" (comum/comunidade), porém agora pelo "tercom". As relações sociais são estabelecidas com base em uma vida "desvivida", no sentido de que experimentar a crueza da vida se tornou algo enfadonho, triste, sem lógica. Certa anestesia mental invadiu as relações. $\mathrm{O}$ contato com o mundo e com o outro passou a ser mediado por instrumentos. Não se pode mais sentir o mundo como ele mesmo é, senão somente por meio das tecnologias. Vivencia-se o prazer existencial, sexual, relacional por meio de sensações virtuais. O real, enquanto ele mesmo, é interpretado por meio de algo não-real. Tempos e espaços variam entre o presencial e o virtual e a configuração da identidade, da memória e da subjetividade se dão de maneira diversa em/entre ambos. O termo virtual pode ser entendido em três sentidos, segundo Pierre Lévy (2000) em um sentido técnico informacional, em um sentido corrente e em um sentido filosófico. Nesta última acepção, segundo o autor, o virtual não é antônimo de real, mas sim

Filosofia e Educação [rfe] - volume 8, número 1 - Campinas, SP

Fevereiro-Maio de 2016 - ISSN 1984-9605 - p. 133-162 
se opõe ao atual, pois "virtualidade e actualidade são apenas duas formas diferentes da realidade. Se é da essência da semente produzir uma árvore, a virtualidade da árvore é bem real (sem ser ainda actual)" (Lévy, 2000, p. $51)$.

Percebe-se também que na vida adulta é cada vez mais premente o acesso aos bens de consumo. A disponibilidade facilitada de aquisição de uma infinidade de cartões de crédito faz com que os homens e mulheres se tornem inadimplentes justamente porque anseiam pelos objetos que encontram, seja pela tela da TV ou do computador. Tal anseio remete a um desejo irrefreado de posse, de falso domínio e de alívio. Os compradores compulsivos não são apenas "doentes mentais", ao contrário, são seres humanos que não foram capazes de refletir sobre as consequências nefastas do desejo ou foram convencidos sem a menor chance de qualquer reação contrária. O marketing "agressivo" faz com que o consumidor seja movido a desejar e a ser incitado pela vontade, pois como afirma Schopenhauer (2005), a vontade é ilimitada e o resultado disso é a frustração e a tristeza decorrentes da impossibilidade da aquisição dos bens desejados.

Entre querer e alcançar flui sem cessar toda vida humana. O desejo, por sua própria natureza, é dor; já a satisfação logo provoca saciedade: o fim fora apenas aparente: a posse elimina a excitação, porém o desejo, a necessidade aparece em nova figura (Schopenhauer, 2005, p. 404).

A incessante insatisfação do desejo desperta nas pessoas um ad eternum de frustração. Em outras palavras, como o desejo não tem objeto definido e vai sendo alterado perpetuamente, o ser humano se vê desamparado, fraco, nu. Essa nudez do desejo o leva ao preenchimento 
constante desse vazio, mesmo que aquilo que se quer seja indefinido. Muitos pensadores da Escola de Frankfurt, ou ligados a ela, abordaram o tema da "insatisfação programada" decorrente da contínua obsolescência do desejo. Adorno, Horkheimer e Benjamim podem ser considerados aqueles que mais discutiram tais temas na esteira do pensamento marxiano. Desse modo, é assaz necessário dizer que Marx já afirmara em $O$ Capital que

a mercadoria é misteriosa simplesmente por encobrir as características sociais do próprio trabalho dos homens, apresentando-as com características materiais e propriedades sociais inerentes aos produtos do trabalho; por ocultar, portanto, a relação social entre os trabalhos individuais dos produtores e o trabalho total, ao refleti-la como relação social existente, à margem deles, entre os produtos do seu próprio trabalho. Através dessa dissimulação, os produtos do trabalho se tornam mercadorias, coisas sociais, com propriedades perceptíveis e imperceptíveis aos sentidos (Marx, 1980, p. 81).

O prelúdio de Marx assume vestes macabras no período dos anos 30 e 40 do século XX, período no qual a Escola de Frankfurt foi fundada e ocorreu a $2^{\mathrm{a}}$ Guerra Mundial, pois a mercadoria fetichizada é a mercadoria da morte. A morte de inúmeros judeus que são perseguidos pelo nazismo, a morte de pessoas que devem ser eliminadas pelo simples fato de existirem. A existência agora é motivo de ódio, de rancor. Um nós deve aniquilar um eles. A morte é a principal fonte de renda nesse período. Fazer do Holocausto uma máquina de produção, que sistematicamente aniquila e destrói a história de um povo resultando absurdamente na incapacidade de se avaliar a morte do outro como um negócio foi a principal crítica de Hannah Arendt aos perseguidores do povo judeu, incorporados na figura de 
Adolf Eichmann. E essa relação de morte está, segundo Arendt, estritamente ligada a uma ideia de consumo:

Crer que tal sociedade há de se tornar mais "cultivada" com o correr do tempo e com a obra da educação constitui, penso eu, um fatal engano. $O$ fato é que uma sociedade de consumo não pode absolutamente saber como cuidar de um mundo e das coisas que pertencem de modo exclusivo ao espaço das aparências mundanas, visto que sua atitude central ante todos os objetos, a atitude do consumo, condena à ruína tudo em que toca (Arendt, 2003, p. 264).

Seguindo essa reflexão, Foucault (1996, p. 206) afirma que "a morte do outro, a morte da raça má, da raça inferior (degenerada, inferior) é isso que tornará a vida mais sã e mais pura". E o autor continua escrevendo, se questionando "como é possível que um poder político mate, reivindique a morte, exija a morte, mande matar, dê a ordem para matar, exponha a morte não só aos seus inimigos, mas também aos seus cidadãos?" (Foucault, 1996, p. 205).

Outrossim, se a experiência histórica recente não nos desperta à consciência, à crítica e à reflexão, é fundamental fazermos um contraponto com a relação do homem com as mercadorias na atualidade. $\mathrm{O}$ fetiche ainda é o mesmo, porém o foco agora é a manutenção da vida pelo consumismo. O essencial é enfatizar que tudo se tornou mercadoria, porém sem invólucros ou mascaramentos. E isso se vê maximizado com a profusão midiática, informacional, tecnológica e digital. A decepção, contudo, está na cegueira com a qual as pessoas, voluntariamente, se inserem neste círculo vicioso. Porém, como lembra Jaguaribe (2007) em $O$ choque do real: estética, mídia e cultura, "o acesso à realidade é moldado pelos meios de 
comunicação que fornecem, inclusive, os imaginários para a invenção e fabricação do indivíduo" (p. 37).

Regidas pela lógica capitalista da circulação, as imagens imperam, impõem o domínio da aparência e fomentam a alienação social já que dinamitam agenciamentos sociais em prol das fabricações visuais que não convidam ao diálogo, mas à mera passividade da absorção consumista (Jaguaribe, 2007, p. 38).

A existência que, outrora, se fundava numa vida após a morte ou numa ascese espiritualizada, naufraga em um afã de desejos quiméricos e vazios. Quando se compra um bem móvel ou imóvel, o mesmo já engendra uma insatisfação, pois dentro de poucos dias, o mercado já lança um novo produto mais moderno e mais "completo" do que o adquirido. Esse constante update das coisas causa uma sensação de frustração e amargura que geram aquilo que Adorno e Horkheimer chamam de "promissória da felicidade":

A indústria [...] não cessa de lograr seus consumidores quanto àquilo que está continuamente a lhes prometer. A promissória sobre o prazer, emitida pelo enredo e pela encenação é prorrogada indefinidamente: maldosamente, a promessa a que afinal se reduz o espetáculo significa que jamais chegaremos à coisa mesma, que o convidado deve se contentar com a leitura do cardápio (Adorno; Horkheimer, 1985, p. 130-131).

A promessa nunca cumprida resume com clareza o entendimento de que o desejo como algo que precisa encontrar uma resposta imediata é algo evidente. Essa imediatez certamente precisa ser atualizada diariamente, 
constantemente. "A felicidade na palma da sua mão" é uma boa paráfrase, pois a plenitude do desejo se efetiva desse modo. Além disso, nota-se que há também uma visão muito reducionista dos conflitos na vida política na atualidade, pois se crê que a partir do liberalismo, as pessoas seriam capazes de ver o mundo como um lócus de consenso. Tal afirmativa corrobora com a ideia de que vivemos em um mundo que segue a "lógica do doce comércio", do laissez faire. Por isso, politicamente falando, podemos destacar o que Chantal Mouffe afirma sobre o cenário político atual:

As sociedades democráticas encaram atualmente um desafio para o qual estão mal preparadas a responder. Longe de ter conduzido a uma suave transição para a democracia pluralista, o colapso do comunismo abriu caminho para uma explosão de conflitos étnicos, religiosos e nacionalistas que muitos liberais não podem compreender. Na visão destes, os antagonismos pertencem a uma era passada, a um tempo pré-moderno, quando as paixões não tinham ainda sido eliminadas pelo 'doce comércio' e substituídas pelo domínio racional dos interesses e pela generalização das identidades 'pós-convencionais'. Daí a dificuldade dos pensadores democráticos liberais para compreender a proliferação atual dos particularismos e a emergência de antagonismos supostamente 'arcaicos' (Mouffe, 2003, p. 12).

Contudo, voltando ao problema do consumismo e da "doce domesticação midiática", o acesso aos bens de consumo se tornou algo tangível para muitos em nossa contemporaneidade. Os sujeitos são vítimas de toda uma avalanche de estímulos e incitações que afloram na sensibilidade. Os padrões estéticos, os padrões éticos e os padrões de consumo se unificaram diante do marketing que se dá de diversas formas: presencial, à distância, virtual, local, global. E a lógica que mais se perpetua 
com isso é a seguinte: não deve haver distinção entre o ser e o ter. Konder $(2009$, p. 90) aponta que a ideologia capitalista dominante impõe que "se o sujeito humano não existe, tudo é vendável, tudo pode ser objeto de compra e venda". Na sequência, o autor constata que "os sujeitos humanos, cada vez mais, estão sumindo; uns desaparecem nas grandes empresas, nas sociedades anônimas; outros somem atrás dos objetos-mercadorias" (Konder, 2009, p. 90), que, segundo o pensador, atualmente possuem mais visibilidade que os próprios sujeitos produtores e consumidores.

Cria-se uma nova noção de estética: a aparência vale mais do que a essência. Aliás, deve haver uma nova distinção estética, mais forte e cruel: a aparência suplantou a essência. Essa noção estética não tem a ver com um modo de ser ou de se viver, mas infelizmente está conectada a um saberpoder-ter. Os saberes se redundaram a uma forma de vida que implica numa objetivação do ser. As subjetividades foram exterminadas tendo como fim a plenitude de um modo de vida igualmente padronizado e reificado. É uma ontologia do aqui e agora. Uma plenificação de um modelo de vida que coisifica o ser humano em um objeto desprovido de valores, de sentimentos, de identidade. Ele deve ser o que é como coisa e não como sujeito que pensa, que critica, que analisa. Ele apenas precisa imitar um modelo que o coloque no mundo como um número, um objeto e isso basta. Essa discussão nos remete à reflexão de Jaguaribe, sobre a atualização do conceito de fetiche a partir das tradições marxista e freudiana.

Qual seria a versão moderna na palavra fetiche? Embora possa existir algumas variações sobre o início histórico do termo fetiche, há um consenso acadêmico que situa este conceito em duas vertentes básicas. Por um lado, o fetiche está associado à interpretação psicanalítica, notadamente a análise de Freud que compreende o fetiche como

Filosofia e Educação [rfe] - volume 8, número 1 - Campinas, SP

Fevereiro-Maio de 2016 - ISSN 1984-9605 - p. 133-162 
resultante de uma ansiedade de castração propiciada pela visão do sexo feminino. [...] A outra associação possível com a palavra fetiche é dada pela óptica de Marx que situa o fetichismo como o encantamento com mercadorias e objetos em que estes são dotados de significados imanentes que obscurecem o trabalho histórico espoliativo que fora acionado para sua fabricação. Em ambas as versões, há o deslocamento do desejo e uma forte ênfase na visualidade como provocadora do fetiche (Jaguaribe, 2007, p. 188).

Além disso, um dos fundamentos principais da teoria da história e das categorias de tempo e de construção do conhecimento de Walter Benjamin é a contraposição ao conceito de progresso, visto dentro de uma teleologia, a qual está fadado o desenvolvimento tecnológico da humanidade. Benjamin denuncia já em sua época que o progresso da ciência não é sinônimo de desenvolvimento da humanidade, mas "ele o seria se, com o crescimento dos conteúdos de verdade acumulados, aumentasse igualmente a participação dos seres humanos nestes conhecimentos" (2009, p. 522-523). Benjamim desenvolve tal reflexão em diversos textos, mas, principalmente, no $O$ anjo da História, ao fazer uma análise de uma imagem de Paul Klee, o Angelus Novus.

Há um quadro de Klee intitulado Angelus Novus. Representa um anjo que parece preparar-se para se afastar de qualquer coisa que olha fixamente. Tem os olhos esbugalhados, a boca escancarada e as asas abertas. $\mathrm{O}$ anjo da história deve ter esse aspecto. Voltou o rosto para o passado. A cadeia de fatos que aparece diante dos nossos olhos é para ele uma catástrofe sem fim, que incessantemente acumula ruínas sobre ruínas e lhas lança aos pés. Ele gostaria de parar para acordar os mortos e reconstituir, a partir dos seus fragmentos, aquilo que foi

Filosofia e Educação [rfe] - volume 8, número 1 - Campinas, SP

Fevereiro-Maio de 2016 - ISSN 1984-9605 - p. 133-162 
destruído. Mas do paraíso sopra um vendaval que se enrodilha nas suas asas, e que é tão forte que o anjo já não as consegue fechar. Esse vendaval arrasta-o imparavelmente para o futuro, a que ele volta as costas, enquanto o monte de ruínas à sua frente cresce até o céu. Aquilo a que chamamos o progresso é este vendaval (Benjamim, 2013, p. 14).

Em outras palavras, podemos dizer que a visão de Benjamin diante do futuro da humanidade é aterradora, pois os eventos atuais tornam isso claro: a falta de água em vários países do mundo, a destruição constante do planeta devido a insaciável marcha do progresso do capitalismo tardio, a evidente desigualdade social, o modo de produção serializado e uniformizador, a violência contras as minorias, inclusive professores. Os avisos não são de ontem, eles já foram declarados há quase um século atrás.

A ideia de progresso atacada por Benjamin, e que deixa o Anjo da História estupefato se assemelha aos encantamentos tecnológicos atuais que encobrem e, por vezes impedem uma leitura histórica, social, política, e cultural, a qual o filósofo alemão convoca a reflexão e ao combate. Pensar o desenvolvimento técnico e tecnológico como sinônimos e garantias de progresso, principalmente em termos de democracia e justiça dos bens sociais, políticos, culturais, econômicos entre outros, é uma ilusão, ou, para usar um termo do próprio Benjamin, uma fantasmagoria.

Por outro lado, a Aufklärung defendida por Kant (1980) agora se tornou um modo de esclarecimento às avessas, no qual a mediocridade se faz patrona da verdade. O medíocre se tornou o porta-voz do mundo. A fórmula mais verdadeira que resume tal assertiva está na inversão da frase cartesiana que vai do "penso, logo existo" para um "consumo, logo existo". 
É evidente que se está fazendo uma inferência indutiva à ideia cartesiana, mas de qualquer modo, a expressão ainda assim é portadora de sentido.

Quais serão as ruínas que ficarão depois de nós? À essa pergunta, muitas respostas podem ser dadas, porém um dos problemas mais evidentes que constatamos é a falta de uma compreensão mais clara das consequências futuras das ações atuais, que Hans Jonas (1995/2006) defende em seu livro O Princípio Responsabilidade, ensaio de uma ética para a civilização tecnológica. Na linha de estudos inaugurada por Kant (1980), que visa despertar a importância de imperativos categóricos para a ação, Jonas depõe a favor de uma reconfiguração da ação humana que não paira mais no agente singular, mas que atinge prioritariamente a coletividade. Se o viés kantiano estava tomado por um modo de agir que preconizava uma ação do "si para o outro", tomado por um telos universal visando o ontem para o hoje, Jonas declara que as ações humanas precisam ter como fim a coletividade pensando o hoje para o futuro. Como afirmam Claúdia Battestin e Gomercindo Ghiggi (2010, p. 71).

no período moderno, o imperativo categórico kantiano foi mantido como sendo exemplar por muito tempo, tendo a pretensão de negar tudo que fosse extra-humano. Kant formulou seu imperativo com o seguinte propósito: 'Age apenas segundo uma máxima tal que possas ao mesmo tempo querer que ela se torne lei universal' (Kant, 1980, p. 129). Ou seja, age de tal maneira que o princípio de tua ação se transforme numa lei universal. O imperativo de Kant é um caso extremo da ética da intenção, obedecendo à ação individual, válido no plano individual. Este imperativo dirige-se ao imediato e só requer a consistência do ato consigo mesmo.

Filosofia e Educação [rfe] - volume 8, número 1 - Campinas, SP

Fevereiro-Maio de 2016 - ISSN 1984-9605 - p. 133-162 
Em contraponto ao princípio kantiano, Battestin e Ghiggi (2010) defendem que Jonas avança ao apontar o papel da responsabilidade que todos os seres humanos devem ter diante do mundo e da importância da reflexão acerca das próprias ações.

O Princípio Responsabilidade, além de ser considerado um princípio ético, proporciona uma perspectiva de diálogo crítico em plena era tecnológica. Jonas entende que, "sob o signo da tecnologia, a ética tem a ver com ações de um alcance causal que carece de precedentes [...]. tudo isso coloca a responsabilidade no centro da ética" (Jonas, 1995, p. 16-17). Hans Jonas formulou um novo e característico imperativo categórico, relacionado a um novo tipo de ação humana: "Age de tal forma que os efeitos de tua ação sejam compatíveis com a permanência de uma vida humana autêntica sobre a terra" (Jonas, 1995, p.40). O imperativo proposto por Hans Jonas é de ordem racional para um agir coletivo como um bem público e não individual (Battestin, Ghiggi, 2010, p. 71).

Essa inversão do telos da ação humana apontada por Jonas pode ser considerada como um novo meio para se refletir as consequências do consumismo e da ação devastadora do desejo ilimitado, isto é, Jonas critica as ações humanas que estão direcionadas apenas para o uso desmedido dos recursos do planeta. Sua visão diante do futuro não é nada promissora, tal como Benjamim aponta. Contudo, apesar dos avisos já ouvidos, é fundamental a reflexão de que o papel do ser humano diante da vida como um todo é repensar o que se almeja com aquilo que se deseja. Dito de outro modo, o ser humano precisa saber equilibrar as suas ações e as suas consequências. Como afirma Jonas: 
[...] Trata-se de saber se, sem restabelecer a categoria do sagrado, destruída de cabo a rabo pelo Aufklärung (Iluminismo) científico, é possível ter uma ética que possa controlar os poderes extremos que hoje possuímos e que nos vemos obrigados a seguir conquistando e exercendo. [...] Mas uma religião inexistente não pode desobrigar a ética de sua tarefa; da religião pode-se dizer que ela existe ou não existe como fato que influencia a ação humana, mas no caso da ética é preciso dizer que ela tem que existir. Ela tem de existir porque os homens agem, e a ética existe para ordenar suas ações e regular seu poder de agir. Sua existência é tanto mais necessária, portanto, quanto maiores forem os poderes de agir que ela tem de regular. (Jonas, 2006, p. 65-66).

Em outras palavras, sabe-se que há um universo de políticas que tentam retomar o cuidado com o humano e com o planeta, porém, nem sempre essas políticas levam em consideração o viés ético e, por isso, logo são abafadas ou esquecidas. Como Jonas afirma, o viés religioso é facultativo, mas o aspecto ético é o mais importante na avaliação das ações humanas, pois todo ser humano age. Agir eticamente (como função por excelência da atividade filosófica) é a principal prerrogativa para a educação e para a política, porém, sempre é o aspecto mais olvidado. A responsabilidade humana deve ser mensurada pela ética pois do ponto de vista tecnológico, nos parece, que o primeiro ponto que impede o seu suposto progresso é a sua voz. É preciso rever as implicações do progresso pelo olhar crítico da ética filosófica.

Porém, tudo isso pode aparentar ser apenas uma elucubração, pois o denominado biopoder, afirmado por Foucault e presente em muitos pensadores atuais, tornou a vida humana escrava de um exercício de poder 
que esquadrinha e monitora constantemente a vida humana, inclusive, no que se refere à sexualidade como "fonte da própria vida".

[...] A partir do século XVI, a 'colocação do sexo em discurso', em vez de sofrer um processo de restrição, foi ao contrário, submetida a um mecanismo de crescente incitação; que as técnicas de poder exercidas sobre o sexo não obedeceram a um princípio de seleção rigorosa mas, ao contrário, de disseminação e implantação das sexualidades polimorfas e que a vontade de saber não se detém diante de um tabu irrevogável, mas se obstinou - sem dúvida através de muitos erros - em se constituir uma ciência da sexualidade (Foucault, 1988, p. 17-18).

Sendo assim, vê-se com evidência que o controle sobre a vida não se redunda apenas a fiscalizar as ações e as intenções humanas, mas acima de tudo, as formas de perpetuação da própria vida. Entre o permitido e o proibido, entre os "sim" e os "não", temos limitações e cerceamentos que configuram uma práxis de monitoramento da vida. Uma moral, que se tornou mais coercitiva do que a própria lei. Um saber que engendra uma maneira de visualizar a própria existência como algo que deve ser objeto de estudo científico. Um discurso que tenta amplificar a teia de poder e vigilância sobre as pessoas.

Se, de um lado, temos a ideia foucaultiana de um controle sobre a vida que perpassa o aparato sociopolítico, temos pelo viés frankfurtiano, uma visão de reificação do ser humano, que não se vê nos objetos produzidos e que, por isso mesmo, são fantasmagóricos, providos de vida própria e detentores de um poder que ultrapassa o óbvio. É a total redução do sujeito a um objeto, que por um lado, é manipulado pelo sistema político e que, por outro, é manipulado pelas coisas.

Filosofia e Educação [rfe] - volume 8, número 1 - Campinas, SP

Fevereiro-Maio de 2016 - ISSN 1984-9605 - p. 133-162 
Assim afirma Nádia Paulo Ferreira (2010, p.426):

[...] Não basta produzir mercadorias, é preciso gerar demandas. Da sigla do objeto, se extraem as imagens em torno das quais se constrói o discurso da publicidade. A função da marca é introduzir o objeto numa rede de associações significantes, fazendo com que se individualize e adquira significações que o tornem desejável. Só assim o objeto se torna sustentáculo da promessa de um gozo-a-mais. Tratase de uma estratégia que se constrói a partir do que é próprio da estrutura de um ser submetido às leis da linguagem. Se uma das faces da castração é o não haver da relação sexual, logo, o que se vende é o que não há para ser comprado. Mas se não há, é por isto mesmo que os objetos são apresentados como fetiches para tomar o lugar de um parceiro humano e gerar relações de dependência que venham substituir os laços entre os homens.

Até aqui o nosso intento foi o de demonstrar a importância do pensamento hodierno acerca da vida humana ou, melhor, nosso intento foi o de apresentar de que maneira a vida humana foi mensurada, controlada e manipulada pelos modos de consumo e de vivência em sociedade. A partir desse entendimento, podemos compreender que a vida humana passou a ser objetivada e reificada, isto é, a vida humana reduzida a res. Essa res, a qual o ser humano se transformou agora é colocada em evidência no mundo político e no mundo educacional, principalmente se o fenômeno for analisado pela maximização da sujeição da própria noção de identidade: o que significa ser professor, por exemplo? Como vimos no ano de 2015, especificamente, em 29 de abril, professores do Estado do Paraná foram escorraçados e violentados pela ação truculenta da Polícia Militar por ordem do governador Beto Richa, que por se sentir ameaçado "pela voz" dos 
professores que reivindicavam seus direitos trabalhistas e se manifestavam contrários à sua ação ditatorial de "subsumir" com o instituto previdenciário. Esse ato desferido contra pessoas que assumiram o papel de educadores e comunicadores da educação demonstra que a violência atinge a todos aqueles que buscam sair ou não aceitar uma condição de reificação. O Angelus Novus apontado por Benjamim ainda sobrevoa os nossos campos que se assemelham, mesmo que metaforicamente, aos campos de concentração nazistas. Um chefe de Estado que age, desse modo, contra os seus professores apenas sublinha com veemência o seu autoritarismo e a noção de que todos devem obedecer a uma única lógica bem antiga mas sempre nova: diante do poder, só se deve obedecer. A valorização da identidade e da diversidade dos papeis sociais se evaporam em uma massa informe e sem rosto. Como afirma Renato Russo, vocalista da banda Legião Urbana, em sua canção Aloha: "E meus amigos sentem medo de quem fala o que sentiu, de quem pensa diferente. Nos querem todos iguais, assim é bem mais fácil nos controlar e mentir, mentir, mentir e matar, matar, matar. $\mathrm{O}$ que eu tenho de melhor: minha esperança".

\section{Lições políticas, filosóficas e educacionais}

Segundo Matos (2009, p. 66), o capitalismo contemporâneo produz fantasmagorias e "a política confunde-se com a economia, nada mais escapando às determinações do mercado". Diante disso, nos questionamos com qual finalidade e em quais dimensões podemos, realmente, problematizar o que ocorreu em 29 de abril: irracionalidade políticopartidária, interesses sindicais ou, uma vez que tais fatos aconteceram em uma praça pública (ágora), quais outros caminhos e desfechos teriam sido possíveis? Se levarmos em consideração o que Matos $(2009$, p. 63) aponta 
quando escreve: "a polis é lugar de pensamento e de memória histórica", podemos concluir que é necessário levar a discussão para a praça pública com respeito, transparência e democracia dialógica e polifônica, garantindo que a voz de todos os atores sociais envolvidos possa ser ouvida.

$\mathrm{O}$ risco que a lógica capitalista predomine nas perspectivas das questões de política e de educação devem ser confrontadas, como descrito na parte teórica deste artigo, em termos de choque, de fetichização e reificação.

Os choques da modernidade atingem as pessoas na economia, pela produção em série; na política, pelos golpes de Estado e os autoritarismos; na vida cotidiana, pelos perigos que o homem moderno recebe e devolve, como um autômato no meio da multidão; na arte e na literatura, porque as obras se tornam mercadorias. (Kramer, 2009, p. 292-293)

Evitando, mesmo com dificuldade, um posicionamento político ideológico ou a emissão de um juízo de valor particular, individual e pessoal, acreditamos que as transformações tecnológicas vivenciadas em nossa sociedade devem se refletir em novas agendas de discussão das estruturas políticas e educacionais existentes. Nesse cenário, a filosofia tem um papel importante a cumprir, por um lado, lembrando a constituição histórica das ideias de cada um desses campos e, por outro, apontando as consequências de determinados princípios e bases de ideias que guiam e geram ações e políticas públicas e educacionais.

Diante de questionamentos, como por exemplo: a ação policial foi de pura obediência? Se o professor (funcionário público) que luta por seu direito é agredido por um policial (também funcionário público), é o Estado que se põe contra ele mesmo? O que aconteceu foi confronto ou massacre?, 
Houve invasão ou ocupação? Os sujeitos eram de movimentos infiltrados, sociais, sindicais ou políticos? Todas essas questões são pertinentes, mas não conseguimos, contudo, nenhuma resposta satisfatória para elas. Pensamos, outrossim, ser mais importante, ao final deste texto, evitarmos veredictos maniqueístas para, em todas as dimensões e fatores envolvidos, apontar as interfaces entre política, educação e filosofia, elementos que, por sua vez, estão coligados a um projeto de sociedade que queremos edificar. Em tal projeto de sociedade, devemos ter claro o que queremos: uma escola e uma educação em função da economia, da política, da filosofia ou dos cidadãos que por ela pagam e dela dependem para se emanciparem? E, nesse ponto, Paulo Freire (2013, p. 98), o Patrono da Educação Nacional, é enfático ao afirmar que "é uma imoralidade, para mim, que se sobreponha, como se vem fazendo, aos interesses radicalmente humanos, os de mercado".

Não nos faltam elementos importantes que emergem no cenário educacional, político e filosófico brasileiro atual, os quais seriam matériasprimas fundamentais para tal empreitada, como por exemplo, o movimento "Escola sem partido" e a discussão acerca da ideologia de gênero que tanto fomentou embates nas elaborações dos Planos Nacional e Estaduais de Educação. Tais discussões poderão ser fonte de outras análises e reflexões.

Concordamos com a defesa feita por Paulo Freire $(2013$, p. 85) de que “ensinar exige disponibilidade para o diálogo" e, ainda, alargamos essa ideia para o campo da política, que talvez pudesse ser apontado como um fator que teria evitado a ação do 29 de abril, no Paraná:

Nas minhas relações com os outros, que não fizeram necessariamente as mesmas opções que fiz, no nível da política, da ética, da estética, da pedagogia, nem posso partir de que devo 'conquistá-los', não importa

Filosofia e Educação [rfe] - volume 8, número 1 - Campinas, SP

Fevereiro-Maio de 2016 - ISSN 1984-9605 - p. 133-162 
a que custo, nem tampouco temo que pretendam 'conquistar-me'. É no respeito às diferenças entre mim e eles ou elas, na coerência entre o que faço e o que digo, que me encontro com eles ou com elas. É na minha disponibilidade à realidade que construo a minha segurança indispensável à própria disponibilidade. É impossível viver a disponibilidade à realidade sem segurança, mas é impossível também criar a segurança fora do risco da disponibilidade (Freire, 2013, p. 132, grifo do autor).

Essa disponibilidade para o diálogo e para o outro, concreto e real e não fetichizado e reificado, é que determinará qual projeto de sociedade apostamos e qual projeto de educação e de política queremos construir, pois

A educação é o ponto em que decidimos se amamos o mundo o bastante para assumirmos a responsabilidade por ele e, com tal gesto, salvá-lo da ruína que seria inevitável não fosse a renovação e a vinda dos novos e dos jovens. A educação é, também, onde decidimos se amamos nossas crianças o bastante para não expulsá-las de nosso mundo e abandoná-las a seus próprios recursos, e tampouco arrancar de suas mãos a oportunidade de empreender alguma coisa nova e imprevista para nós, preparando-as para a tarefa de renovar um mundo comum (Arendt, 2003, p. 247).

No texto Educação após Auschwitz no qual Adorno (2010, p. 117ss) defende que a exigência primeira de toda educação é a de que essa tragédia histórica não se repita, o autor defende a necessidade de uma "educação dirigida a uma auto-reflexão crítica" (p. 121). Da mesma forma que Paulo Freire (2013, p. 20, grifo do autor) defende que "somos seres condicionados mas não determinados", Adorno (2010, p. 122-123) diz que devemos abrir 
mão de "comportamentos autoritários e autoridades cegas" em favor de "vínculos de compromisso" e da autodeterminação dos sujeitos sociais. Mais adiante, Adorno (2010, p. 140-141) afirma que a educação e a democracia são exigências políticas e que para uma democracia operar são imprescindíveis homens e mulheres emancipados.

$\mathrm{Da}$ mesma forma que na educação seus sujeitos frequentemente questionam os porquês de estarem aprendendo determinados conteúdos, na política dever-se-ia formar sujeitos políticos que pudessem questionar a moralidade das ações, mesmo as pautadas pela legalidade. Essa qualidade seria a da consciência crítica e autônoma, que Adorno (2010, p. 150) conceitua como "o pensar em relação à realidade, ao conteúdo [...] e à capacidade de fazer experiências”. Nesse sentido, conclui Adorno (2010, p. 150) que "a educação para a experiência é idêntica à educação para a emancipação".

Talvez com esse início de debate que propomos com as diversas lições políticas, filosóficas e educacionais que pretendemos observar no decorrer do texto, estaremos colocando em prática o significado duplo do lema do atual mandato presidencial: Brasil, Pátria Educadora.

Trata-se de lema com duplo significado. Ao bradarmos 'BRASIL, PÁTRIA EDUCADORA' estamos dizendo que a educação será a prioridade das prioridades, mas também que devemos buscar, em todas as ações do governo, um sentido formador, uma prática cidadã, um compromisso de ética e um sentimento republicano (Rousseff, 2015). 


\section{Referências}

ADORNO, Theodor W. Educação e emancipação. Trad. Wolfgang Leo Maar. São

Paulo: Paz e Terra, 2010.

ADORNO, Theodor W.; HORKHEIMER, Max. Dialética do esclarecimento.

Trad. Guido Antonio de Almeida. Rio de Janeiro: Zahar, 1985.

ARENDT, Hannah. Entre o passado e o futuro. Trad. Mauro W. Barbosa. São Paulo: Perspectiva, 2003.

BATTESTIN, Claúdia; GHIGGI, Gomercindo. O princípio responsabilidade de Hans Jonas: um princípio ético para os novos tempos. Revista Thaumazein, Ano III, número 06, Santa Maria (Outubro de 2010), p. 69-85.

BENJAMIN, Walter. O narrador: Considerações sobre a obra de Nikolai Leskov. In: Obras Escolbidas v. 1 - Magia e técnica, arte e política. Trad.

Sergio Paulo Rouanet. São Paulo: Brasiliense, 1985, p. 197-221.

Passagens. Edição alemã de Rolf Tiedemann; organização da edição brasileira Willi Bolle; colaboração na organização da edição brasileira: Olgária Chain Féres Matos; trad. do alemão: Irene Aron; trad. do francês: Cleonice Paes Barreto Mourão. Belo Horizonte: Editora UFMG; São Paulo: Imprensa Oficial do Estado de São Paulo, 2009.

O anjo da História. Trad. João Barrento. 2. ed. Belo Horizonte: Autêntica, 2013.

Bíblia Sagrada - Edição Pastoral. Trad. Ivo Storniolo e Euclides Martins Balancin. São Paulo: Paulus, 1991. 25a impressão (2008), 1265 p.

BOTTER, Bárbara. A pedagogia antes da pedagogia. In: OLIVEIRA, Paulo Eduardo de (org.). Filosofia e educação: aproximações e convergências. Curitiba: Círculo de Estudos Bandeirantes, 2012, p. 19-31.

DELEUZE, Gilles. Conversações. Trad. Peter Pal Pelbart. São Paulo: Editora 34, 2013.

Filosofia e Educação [rfe] - volume 8, número 1 - Campinas, SP

Fevereiro-Maio de 2016 - ISSN 1984-9605 - p. 133-162 
FERREIRA, Nadiá Paulo. Algumas reflexões sobre a contemporaneidade. Revista Trivium, Ano II, 2. Ed. Dez. 2010. (p. 420-431) Disponível em: $<$ http://www.uva.br/trivium/edicoes/edicao-ii-ano-ii/artigos-tematicos/4algumas-reflexoes-sobre-a-contemporaneidade.pdf > Acesso em: 29 out. 2015. FOUCAULT, Michel. Vigiar e Punir: nascimento da prisão. Trad. Raquel Ramalhete. Petrópolis: Vozes, 1987. - História da sexualidade I: A vontade de saber. 14. ed. Rio de Janeiro: Graal, 1988.

- Genealogia del racismo. Trad. Alfredo Tzveibel. La Plata: Editorial Altamira, 1996.

FREIRE, Paulo. Pedagogia da Autonomia: saberes necessário à prática educativa. Rio de Janeiro: Paz e Terra, 2013.

JAGUARIBE, Beatriz. O choque do real: estética, mídia e cultura. Rio de Janeiro: Rocco, 2007.

JONAS, Hans. El principio del responsabilidad: ensayo de una ética para la civilizacion tecnologica. Barcelona: Herder, 1995.

JONAS, Hans. O princípio responsabilidade: ensaio de uma ética para a civilização tecnológica. Trad. Marjane Lisboa e Luiz Barros Montez. Rio de Janeiro: Contraponto; Ed. PUC-Rio, 2006.

JOTA QUEST. Dias melhores. Composição Rogério Flausino. Álbum Oxigênio. Ano de Lançamento: 2000. Gravadora Sony Bmg/Chaos. Faixa 2, tempo 4'46".

KANT, Immanuel. Fundamentação da Metafísica dos Costumes. São Paulo: Abril Cultural, 1980. (Coleção Os Pensadores).

KONDER, Leandro. Benjamin e o marxismo. In: SOUZA, Solange Jobim; KRAMER, Sonia. Política, cidade e educação: itinerários de Walter Benjamin. Rio de Janeiro: Contraponto: Ed. PUC-Rio, 2009, p. 85-94. 
. Educação a contrapelo. In: SOUZA, Solange Jobim; KRAMER, Sonia.

Política, cidade e educação: itinerários de Walter Benjamin. Rio de Janeiro: Contraponto: Ed. PUC-Rio, 2009, p. 289-304.

LEGIÃO URBANA, Aloha. Compositor Renato Russo. Álbum A Tempestade ou o Livro dos Dias. Ano de Lançamento, 1996, Gravadora Ed. Corações Perfeitos (EMI) Faixa 7, tempo 5’25”.

LÉVY, Pierre. Cibercultura. Trad. José Dias Ferreira. Lisboa: Instituto Piaget, 2000 .

MARX, Karl. O Capital: Crítica a Economia Política. Livro I: O processo de produção do capital. Trad. Reginaldo Sant'Ana. 5. ed. Rio de Janeiro: Civilização Brasileira, 1980.

MATOS, Olgária. Walter Benjamin: pólis grega, metrópoles modernas. In: SOUZA, Solange Jobim; KRAMER, Sonia. Política, cidade e educação: itinerários de Walter Benjamin. Rio de Janeiro: Contraponto: Ed. PUC-Rio, 2009, p. 6184.

McLUHAN, Marshall. Os meios de comunicação como extensões do homem. Trad. Décio Pignatari. São Paulo: Cultrix, 2007.

MOUFFE, Chantal. Democracia, cidadania e a questão do pluralismo. Revista Politica e Sociedade, n. 3. Out. 2003. (p. 11-26) UFSC - Florianópolis-SC.

OLIVEIRA, Paulo Eduardo de (org.). Filosofia e educação: aproximações e convergências. Curitiba: Círculo de Estudos Bandeirantes, 2012.

ROUSSEFF, Dilma. Discurso da Presidenta da República, Dilma Rousseff, durante Compromisso Constitucional perante o Congresso Nacional. (Palácio do Planalto) Jan. 2015. Disponível em: < http://www2.planalto.gov.br/acompanhe-o-planalto/discursos/discursos-dapresidenta/discurso-da-presidenta-da-republica-dilma-rousseff-durantecompromisso-constitucional-perante-o-congresso-nacional-1>. Acesso em: 30 out. 2015.

Filosofia e Educação [rfe] - volume 8, número 1 - Campinas, SP

Fevereiro-Maio de 2016 - ISSN 1984-9605 - p. 133-162 
SARTRE, Jean Paul. O existencialismo é um humanismo; A imaginação; Questão de método. Seleção de textos de José Américo Motta Pessanha. Trad. Rita Correira Guedes, Luiz Roberto Salinas Forte, Bento Prado Júnior. 3. ed. São Paulo: Nova Cultural, 1987.

SCHOPENHAUER, Artur. O mundo como vontade e como representação. $1^{\circ}$ tomo. Trad., apresentação, notas e índices de Jair Barboza. São Paulo: Editora UNESP, 2005. 